\title{
Szanowni Państwo, Drodzy Czytelnicy
} Ladies and Gentlemen, Dear Readers

Dwudziesty czwarty numer wydawnictwa zatytułowany „Woda i zieleń w architekturze" jest tematycznie związany z numerem dwudziestym drugim. Został także poświęcony w aspektach związanych z wodą i zielenią wszelkim zagadnieniom architektoniczno - urbanistycznym związanym z kształtowaniem współczesnych miejskich przestrzeni w strefach zurbanizowanych Ziemi. Tematycznie zawiera zagadnienia związane m.in.:

- $\mathrm{z}$ architekturą krajobrazu, planowaniem przestrzennym z udziałem terenów zielonych i zbiorników wodnych,

- z rewitalizacją miejskich terenów poprzemysłowych i nadwodnych oraz przestrzeni publicznych z udziałem wody i zieleni,

- ze stosowaniem nowoczesnych rozwiązań technologicznych dla kształtowania budynków z zielonymi ścianami, dachami lub powiązanych ze zbiornikami wodnymi, z systemami gospodarowania wodą deszczową w budynkach i przestrzeniach publicznych,

- z estetyką i kompozycją przestrzenną w kształtowaniu współczesnych przestrzeni miejskich za pomocą różnorodnych typów zieleni oraz elementów wodnych,

- z kształtowaniem zabudowy i przestrzeni społecznych z udziałem wody i zieleni w środowisku mieszkaniowym etc.

Opublikowanych zostało dwadzieścia artykułów autorów reprezentujących jednostki naukowe z Barcelony, Grazu, Kielc, Kijowa, Krakowa, Łodzi, Szczecina oraz Warszawy. W niniejszym numerze zostały zaprezentowane także studenckie projekty architektoniczno - urbanistyczne w artykule „Woda i zieleń w architekturze jednorodzinnych domów wolno stojących". Pokazują one kreacje wody i zieleni w kształtowaniu architektury jednorodzinnych domów wolno stojących w kontekście naturalnego otoczenia.

Zapraszam Szanownych Państwa do zapoznania się z kolejnym numerem naszego wydawnictwa. Mam nadzieję, że spełni ono Państwa oczekiwania.
The twenty-fourth issue of our periodical, entitled "Water and greenery in architecture", is thematically associated with the twenty-second issue. It has also been dedicated, in aspects associated with water and greenery, to all architectural and urban-planning related subjects concerning the shaping of contemporary urban spaces in Earth's urbanised areas.

Thematically it includes matters associated with, among others:

- landscape architecture, spatial planning involving green areas and bodies of water,

- the urban regeneration of post-industrial areas and riverfronts, as well as public spaces involving water and greenery,

- the use of modern technological solutions in the shaping of buildings featuring green walls and roofs or that are linked with water bodies, systems of rainwater management in buildings and public spaces,

- with aesthetics and spatial composition in the shaping of contemporary urban spaces using various types of greenery and water features,

- with the shaping of buildings and social spaces involving water and greenery in the housing environment, etc.

Twenty articles by authors representing scientific facilities from Barcelona, Graz, Kielce, Kiev, Krakow, Łódź, Szczecin and Warsaw have been published. The issue also features a presentation of students' architectural and urban designs included in the article "Water and greenery in the architecture of single-family detached houses". They show designs of water and greenery in the shaping of the architecture of detached single-family houses in the context of natural surroundings.

Ladies and Gentlemen, I would like to invite You to peruse another issue of our periodical. I hope that it will meet Your expectations.

\section{MACEAR SRULA}

Translation by Krzysztof Barnaś 